\title{
Occurrence and Seasonal Monitoring of Domoic Acid in Three Shellfish Species from the Northern Adriatic Sea
}

\author{
Kristina Kvrgić $^{1}{ }^{(1)}$, Tina Lešić ${ }^{2}$, Natalija Džafić ${ }^{1}$ and Jelka Pleadin ${ }^{2, *(1)}$ \\ 1 Veterinary Centre Rijeka, Croatian Veterinary Institute, Podmurvice 29, 51000 Rijeka, Croatia; \\ kvrgic.vzr@veinst.hr (K.K.); dzafic.vzr@veinst.hr (N.D.) \\ 2 Laboratory for Analytical Chemistry, Croatian Veterinary Institute, Savska Cesta 143, 10000 Zagreb, Croatia; \\ lesic@veinst.hr \\ * Correspondence: pleadin@veinst.hr
}

Citation: Kvrgić, K.; Lešić, T.; Džafić, N.; Pleadin, J. Occurrence and Seasonal Monitoring of Domoic Acid in Three Shellfish Species from the Northern Adriatic Sea. Toxins 2022, 14, 33. https://doi.org/10.3390/ toxins 14010033

Received: 27 October 2021 Accepted: 31 December 2021 Published: 3 January 2022

Publisher's Note: MDPI stays neutral with regard to jurisdictional claims in published maps and institutional affiliations.

Copyright: (C) 2022 by the authors. Licensee MDPI, Basel, Switzerland. This article is an open access article distributed under the terms and conditions of the Creative Commons Attribution (CC BY) license (https:// creativecommons.org/licenses/by/ $4.0 /)$.

\begin{abstract}
As filter feeders, bivalves and ascidians can accumulate contaminants present in the environment and pass them on to higher food chain levels as vectors. The consumption of bivalves contaminated with the potent neurotoxin domoic acid (DA) can cause amnesic shellfish poisoning in humans. The aim of this study was to determine seasonal differences in occurrence and accumulation of this phycotoxin in European oysters (Ostrea edulis Linnaeus, 1758) $(n=46)$, Queen scallops (Aequipecten opercularis Linnaeus, 1758) $(n=53)$, and edible ascidians of the Microcosmus spp. $(n=107)$, originating from the same harvesting area in the Northern Adriatic Sea. The quantification was performed using ultra-performance liquid chromatography-tandem mass spectrometry (LC-MS/MS) preceded by derivatization with dansyl chloride. DA was found in very low concentrations throughout the year, with a maximum value of $810 \mu \mathrm{g} / \mathrm{kg}$ in Queen scallops. This study reveals differences in the occurrence and accumulation of DA between Queen scallops and the other two investigated species (oysters and ascidians) and the highest concentrations during the colder part of the year. Even though DA was detected in all of them, Queen scallops showed higher DA accumulation compared to the other two $(p<0.001)$, hence representing a sentinel species suitable for the monitoring of DA level in seafood.
\end{abstract}

Keywords: domoic acid; seasonal monitoring; bivalves; ascidians

Key Contribution: The results of this study may be of use in the identification of sentinel species suitable for the monitoring of domoic acid level in seafood and may contribute to consumer risk assessment and the widening of knowledge on ascidians as an alternative food source.

\section{Introduction}

Due to its high nutritional value and the absence of additives, the consumption of seafood is essential in preventing non-communicable diseases such as cardiovascular diseases, as well in combating undernutrition and micronutrient deficiencies. Owing to their low amount of fat and a favourable fatty acid profile, as well as to their high share of easily digestible proteins containing essential amino acids, vitamins, and minerals, bivalves play an important role in a healthy and balanced diet [1-4]. Edible tunicate species such as ascidians are marine animals that represent an easily accessible source of valuable nutrients and bioactive compounds [5]. However, as filter feeders, bivalves and ascidians can accumulate contaminants present in the environment and pass them on to higher food chain levels as vectors [6].

The consumption of seafood contaminated with the potent neurotoxin domoic acid (DA) can cause severe amnesic shellfish poisoning (ASP) of humans with a possibly lethal outcome [7]. DA is a heat-stable, water-soluble tricarboxylic amino acid with a secondary amino group [8,9]. It is produced by marine diatom species of the Pseudo-nitzschia genus, 
red algae termed Chondria armata, and some other species belonging to the Rhodomelaecae family [9]. DA toxicity arises from its structural similarity with glutamic acid. As a glutamate agonist, DA binds to the kainate receptors in vital organs, causing neuronal depolarization [10]. The symptoms of intoxication are gastrointestinal, cardiovascular, and neurological in nature, whereas their intensity thereby depends on the ingested DA dose and individual susceptibility [9]. Clinical symptoms of ASP include cramps, vomiting, diarrhoea, headache, disorientation, and a characteristic short-term memory loss, while severe cases present with seizures, coma, and death [8]. The elderly and people with diabetes, kidney disorder, and hypertension seem to be more susceptible to DA. Since it penetrates the placental membrane, its foetal effects are detrimental [9]. Eight DA isomers (DA A-H) and one diastereomer ( $\mathrm{C5}^{\prime}$, or isoDA) have been identified so far, all of them found to be less potent than DA itself [11].

The most common DA vectors are filter-feeding marine organisms such as shellfish, especially mussels, razor clams, and scallops, but DA was also found in crustaceans, octopods, cuttlefish, krill, anchovies, sardines, and planktivorous fish [9,10]. There are differences in the occurrence and concentration of DA between species, even when the latter are exposed to the same environmental influences [12-15]. These differences are attributed to the differences in DA absorption and depuration rates [16]. Some species such as M. edulis [17], M. galoprovincialis [18], Mesodesma donacium [19], and Argopecten purpuratus [20] depurate DA very quickly, unlike Siliqua patula [21] and Pecten maximus [22], which retain this phycotoxin for a long period of time. Even though DA seems to be non-toxic for shellfish, it exerts some adverse effects on bivalves, such as oxidative stress, mitochondrial dysfunction [23], DNA damage [24], haemocyte changes [25], shell closure, haemolymph acidosis, hypoxia [26], negative impact on larval [27] and adult growth rate, and the survival of some shellfish species [28].

This study aimed at determining the differences in occurrence and accumulation of DA in European oysters (Ostrea edulis Linnaeus, 1758), Queen scallops (Aequipecten opercularis Linnaeus, 1758), and edible ascidians of the Microcosmus spp. originating from the same harvesting area in the Northern Adriatic Sea, as well as at establishing seasonal differences in DA accumulation. Since concentrations far below the maximum permitted level (MPL) of $20 \mathrm{mg}$ DA per $\mathrm{kg}$ were expected, the quantification was performed using ultra-performance liquid chromatography-tandem mass spectrometry (LC-MS/MS) preceded by derivatization with dansyl chloride (DNS-Cl) in order to achieve the lower limit of detection (LOD), as compared to the reference high-performance liquid chromatography with diode array detection (HPLC-DAD) method. The results may be of use in the identification of sentinel species suitable for the monitoring of DA level in seafood. Given that data on the occurrence of phycotoxins in European oysters, Queen scallops, and ascidians originating from the Northern Adriatic Sea are scarce, this study may contribute to shellfish-consumption-related consumer risk assessment and the promotion of ascidians as an alternative food source.

\section{Results and Discussions}

\subsection{Validation of Analytical Method}

The analysis of 20 blank samples did not reveal any interference at DA retention time. LOD and LOQ values determined using blanks approach described by Wenzl et al. [29] were similar for all investigated species and approximated to 0.3 and $1 \mu \mathrm{g} / \mathrm{kg}$, respectively. During validation, the certified reference material CRM-FDMT1 was used for method recovery check-up. The obtained recovery ranged from $87 \%$ to $108 \%$, with the average value of $98 \%$. Repeatability, in-house reproducibility, recovery, and measurement uncertainty results are given in Table 1 . Relative standard deviations of repeatability and in-house reproducibility were found to be below $15 \%$, with the average recovery of $94 \%$. These results are compliant with the validation requirements laid down under the Commission Decision 2002/657/EC, speaking to the suitability of this method for DA quantification in the investigated species. 
Table 1. Repeatability, in-house reproducibility, recovery, and measurement uncertainty established for DA determined in Mediterranean mussels, European oysters, Queen scallops, and ascidians ${ }^{\mathrm{a}}$.

\begin{tabular}{ccccccc}
\hline $\begin{array}{c}\text { Calibration } \\
\text { Level }(\boldsymbol{\mu g} / \mathbf{k g})\end{array}$ & $\begin{array}{c}\mathbf{s}_{\mathbf{r}} \\
(\mu \mathbf{g} / \mathbf{k g})\end{array}$ & $\begin{array}{c}\mathbf{R s}_{\mathbf{r}} \\
\mathbf{( \% )}\end{array}$ & $\begin{array}{c}\mathbf{s}_{\mathbf{w R}} \\
(\mu \mathrm{g} / \mathbf{k g})\end{array}$ & $\begin{array}{c}\mathbf{R s}_{\mathbf{w R}} \\
(\mathbf{\%})\end{array}$ & $\begin{array}{c}\text { Recovery } \\
(\mathbf{\%})\end{array}$ & $\begin{array}{c}\Delta \\
(\mathbf{\%})\end{array}$ \\
\hline 50 & 4.3 & 9.5 & 5.3 & 10.6 & 93 & 18 \\
\hline 250 & 19.9 & 8.0 & 21.2 & 8.5 & 94 & 14 \\
\hline 500 & 39.5 & 7.9 & 41.6 & 8.3 & 94 & 14 \\
\hline 1000 & 78.9 & 7.9 & 7.9 & 8.3 & 94 & 14
\end{tabular}

$\overline{\mathrm{DA}}$ (domoic acid), $\mathrm{S}_{\mathrm{r}}$ (repeatability standard deviation), $\mathrm{R}_{\mathrm{Sr}}$ (relative repeatability standard deviation), $\mathrm{S}_{\mathrm{wR}}$ (in-house reproducibility standard deviation), $\mathrm{R}_{\mathrm{SwR}}$ (relative in-house reproducibility standard deviation), $\Delta$ (extended relative measurement uncertainty, $\mathrm{k}=1.645) ;{ }^{\mathrm{a}}$ The total number of samples $(n=128)$ consisting of an equal share of the four species (a quarter of each).

As a part of the validation process, the matrix effect was evaluated due to the possible lack of response or an enhanced response (ion suppression or ion enhancement) in MS/MS detection, caused by coeluting matrix components that can affect the method performance [30,31]. When comparing the slopes of calibration curves of derivatized matrix-matched standards to the derivatized standards prepared in solvent, the difference in ratio of each of those curves higher than $10 \%$ as ion suppression was recorded, common for LC-MS/MS, especially if electro-spray ionisation (ESI) is engaged in the positive ionisation mode [32]. A significant difference was found between the slope of the calibration curve prepared with an ascidian blank matrix and the other two shellfish matrices, so, in order to minimize the matrix effect, matrix-matched calibration prepared with blank extracts of each and every investigated species was used for quantification.

\subsection{Domoic Acid in Bivalves and Ascidians}

The obtained results show the presence of DA in all investigated species. It was present in $36 \%$ of the samples in concentrations significantly lower than the MPL of $20 \mathrm{mg} / \mathrm{kg}$, set out under the Regulation 853/2004/EC [33]. Bivalve and ascidian samples under this study represent a natural three-species population, which grew in the same area of the Northern Adriatic Sea, hence influenced by the same environment. In this way, inter-species differences caused by various environmental conditions seen in different locations were minimized. Table 2 presents the mean values of DA quantified in samples collected during the entire course of the study. The chromatogram of the sample harbouring the highest DA concentration is presented in Figure 1.

Table 2. Domoic acid in bivalves and ascidians originating from the same harvesting area in the Northern Adriatic Sea.

\begin{tabular}{ccccc}
\hline Species & $\mathbf{n}$ & \% of Positives * & $\begin{array}{c}\text { Mean } \pm \text { SE of } \\
\text { Positives * }(\mu \mathrm{g} / \mathbf{k g})\end{array}$ & $\begin{array}{c}\text { Maximum } \\
(\mu \mathrm{g} / \mathbf{k g})\end{array}$ \\
\hline European oysters & 46 & 17 & $65.6 \pm 10.3^{\mathrm{b}}$ & 212 \\
\hline Queen scallops & 53 & 57 & $153 \pm 32.1^{\mathrm{a}}$ & 810 \\
\hline Ascidians & 107 & 33 & $5.5 \pm 0.6^{\mathrm{b}}$ & 24.3 \\
\hline
\end{tabular}

${ }^{*}$ values above LOD; ${ }^{\text {a,b }}$ values within a column tagged with a different superscript differ significantly $(p<0.05)$ SE (standard error).

Statistical analysis revealed a difference in DA accumulation between the species $(p<0.05)$. Ascidians and European oysters showed no significant mutual difference in this regard $(p=0.210)$, whilst the difference between Queen scallops and the other two species-ascidians and oysters-was proven significant $(p<0.001)$. Queen scallops showed the greatest DA accumulation, with $57 \%$ of positives and a mean DA concentration 2.3 -fold higher than that in European oysters. As compared to oysters, DA was detected in almost twice as many ascidian samples, but in lower mean and maximum concentrations. 


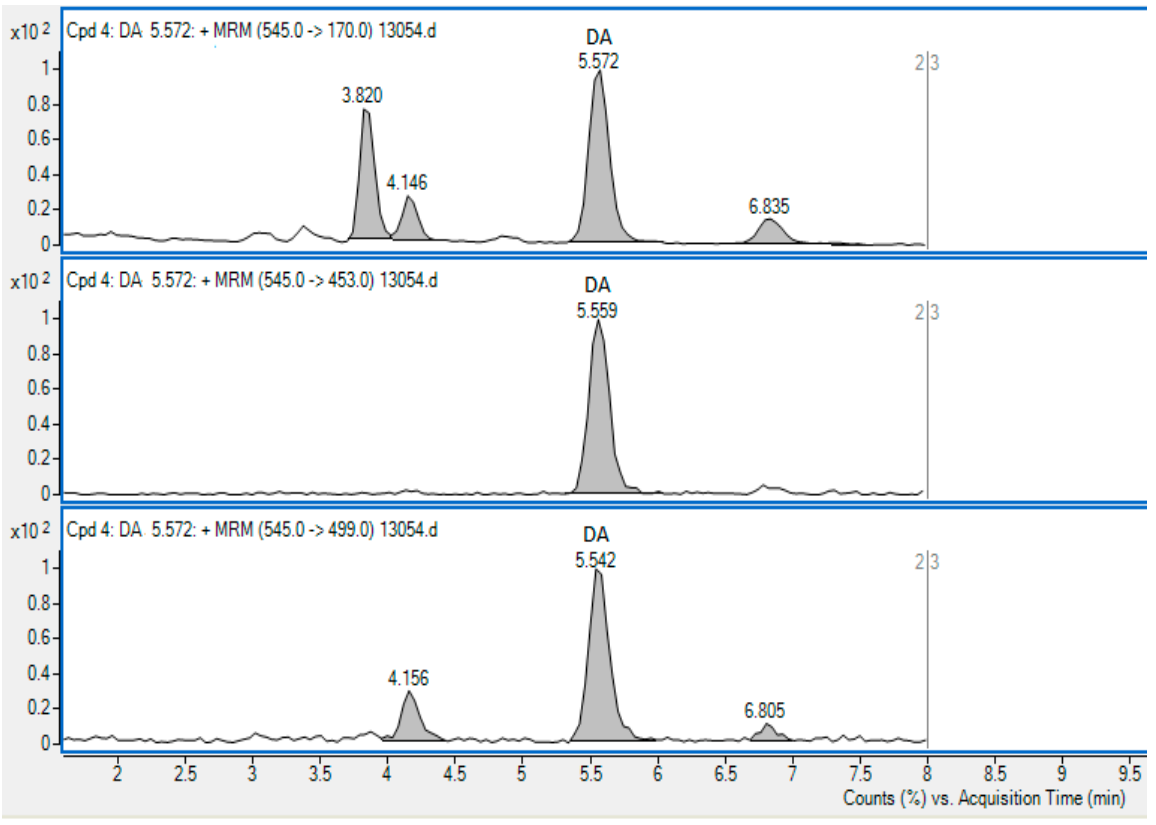

Figure 1. The chromatogram showing the method of SRM transitions used for the detection of DA in the Queen scallop sample containing DA in the concentration of $809.5 \mu \mathrm{g} / \mathrm{kg}$. The $545 \rightarrow 170$ transition (precursor $m / z \rightarrow$ product $m / z$ ) was used for quantification.

The presence of DA in bivalve and ascidian species investigated in this study and the demonstration of differences between their DA accumulation are in line with the previous results obtained for naturally contaminated bivalves gathered from various world seas. Differences in DA accumulation between marine species collected at the same time at the same locality were observed by Ujević et al. [12] in rough cockle Acanthocardia tuberculata and smooth clam Callista chione collected from the Cetina River estuary in the Central Adriatic Sea. In rough cockle, DA was found from April through July 2009 in the maximum concentration of $770 \mu \mathrm{g} / \mathrm{kg}$, while smooth clam was DA-positive in concentration of $280 \mu \mathrm{g} / \mathrm{kg}$ only on a single occasion in April of that year. Bouchouicha-Smida et al. [13] found a greater DA accumulation in oysters Ostrea edulis $(420-1040 \mu \mathrm{g} / \mathrm{kg}$ ) collected from the southwest Mediterranean in August and December 2009, as compared to simultaneously collected M. galloprovincialis (130-860 $\mu \mathrm{g} / \mathrm{kg})$. Takata et al. [14] determined the maximum DA level of $88,160 \mu \mathrm{g} / \mathrm{kg}$ in Spondylus squamosus gathered from the Philippines in March 2006, while other co-occurring species (Perna viridis, Anadara antiquata, Chama iostoma, Chama lazarus, Atrina vexillum, Placuna sella, Hyotissa hyotis) contained DA levels of around $1000 \mu \mathrm{g} / \mathrm{kg}$. Picot et al. [15] found that the dominant DA vector is cockle Cerastoderma edule, in which DA was detected in the highest concentration of $3710 \mu \mathrm{g} / \mathrm{kg}$. Carpet shells of the Ruditapes spp. harboured DA in the concentration of $2580 \mu \mathrm{g} / \mathrm{kg}$, while razor clams (Ensis spp. or Solen spp.) contained $2520 \mu \mathrm{g} / \mathrm{kg}$ of DA. The latter two accumulated more DA than oysters Crassostrea gigas (1730 $\mu \mathrm{g} / \mathrm{kg}$ ) and mussels M. edulis $(1040 \mu \mathrm{g} / \mathrm{kg})$. All of the samples referred to above were collected simultaneously on the French Atlantic coast from June 2009 to June 2010.

The differences elaborated above are species-specific and can be attributed to different accumulation $[16,34,35]$ and elimination rates $[18,22,36]$, gut assimilation $[16,37]$, tissue distribution [19,20,22], and environmental conditions [38]. DA depuration in bivalves is usually explained by two kinetic models [20]. The single-compartment model is characterized by an exponential DA decrease during the entire depuration period and describes DA depuration kinetics in M. edulis [17], P. magellanicus [39], and P. maximus [22]. The twocompartment model is characterized by rapid initial toxin elimination followed by a period of slower elimination. This pattern can be seen in M. galloprovincialis [18], C. virginica [36], and some other species. Due to the dissimilar depuration kinetics, differences are also seen 
between species belonging to the same family. For instance, in the Argopecten purpuratus scallop, DA acquired by the digestive gland is quickly transferred between the organs and rapidly released into the environment [20]. In another scallop, Pecten maximus, the majority of the toxin is accumulated in the digestive gland, the redistribution is limited, and the depuration is very slow $[22,37]$.

According to Vale and Sampayo [40], carpet shell and common cockle contain higher DA concentrations than mussels and oysters. In their research, Mafra et al. [34] found that oysters have a lower capacity for DA accumulation as compared to mussels. This observation was explained by low oyster toxin intake due to the low clearance rate and the capability of selective rejection of Pseudo-nitzschia cells in pseudo-faeces. Faster DA elimination seen in some species such as M. edulis can also be explained by the presence of DA-utilizing bacteria capable of DA degradation in gut flora [41]. On the other hand, in species that retain DA for a longer period, such as the Placopecten magellanicus scallop, those bacteria are rarely found [41]. DA availability is also of great importance-since scallops mostly accumulate DA in their digestive gland, it becomes inaccessible to bacteria [41].

Furthermore, since the species under this study are all suspension feeders that utilise detritus as a food source [42-44], lower accumulation of DA in ascidians and oysters might be related to the lack of particle-sorting mechanism [45] and the dilution of food in the gut when feeding on concentrated high-particle detritus [46]. Newer research shows that some large microalgae cells can evade capture by ascidians due to some of their traits, such as the thick bio-mineralised armour of diatoms [47]. Similar findings are reported by Barillé and Cognie [44], who found a significant post-extracellular digestion survival of diatoms in pseudo-faeces and faeces of the Pacific oyster Crassostrea gigas regardless of cell size. The above is favoured by the dilution of food particles in the digestive system, arising on the grounds of addition of inorganic matter intended to create natural feeding conditions, and possibly also by the resistance of diatom cell walls to digestion [48]. Differences in DA absorption and excretion mechanisms seen in shellfish are investigated on the molecular level as well. Trainer and Bill [21] suggested the presence of high affinity-low capacity and low affinity-high capacity glutamate receptors that prevent DA intoxication of the Pacific razor clam Siliqua patula, which could be responsible for binding and retaining DA for a long period of time. Mauriz and Blanco [49] found DA in the King scallop (Pecten maximus), mostly free in cytosol in a soluble form. Nevertheless, this species retains DA for a long period of time, which was explained by the lack of membrane transporter necessary for DA to pass the plasma membrane. Even though mussels are commonly used for phycotoxins' monitoring purposes, DA concentrations commonly present in them rarely make them the most intoxicated species [13]. Based on the data provided by this research, it can be concluded that, due to their longer DA retention and higher accumulation rate, Queen scallops are sentinel species more suitable for DA monitoring than oysters. Even though the presence of hydrophilic paralytic shellfish toxins and ASP phycotoxins in ascidians has been recorded, even in high concentrations that could pose a threat to human health [50-52], data provided by this study reveal that ascidians accumulate DA in significantly lower concentrations than oysters and scallops.

Findings of low-level presence of DA in shellfish and ascidians, yielded by this study, are in line with the research done in the Adriatic Sea and the Mediterranean area. DA in the maximum concentration of $2500 \mu \mathrm{g} / \mathrm{kg}$ was determined in Italian mussels in 2000 [53], as well as in different parts of the Adriatic Sea in concentrations far below the regulatory limit [54]. In 2005, DA was detected for the first time in Croatian mussels bred on the west side of the Istrian peninsula in concentrations of up to $872 \mu \mathrm{g} / \mathrm{kg}$ in M. galloprovincialis [55]. Within the 2006-2008 timeframe, DA was detected on several occasions in four species (Proteus scallop, Mediterranean scallop, European flat oyster, and blue mussel) bred and harvested in the Central and Northern Adriatic, in the highest concentration of $6549 \mu \mathrm{g} / \mathrm{kg}$ in M. galloprovincialis samples collected from the Central, along with $1657 \mu \mathrm{g} / \mathrm{kg}$ in $P$. jacobeus samples collected from the Northern Adriatic [56]. In 2007, Rijal Leblad et al. [57] reported the highest DA concentration of $4900 \mu \mathrm{g} / \mathrm{kg}$ found in sweet clam (C. chione) and $2110 \mu \mathrm{g} / \mathrm{kg}$ 
found in tuberculate cockle (A. tuberculata) originating from the Mediterranean coast of Morocco. The highest level of DA detected in Tunisian oysters was $1040 \mu \mathrm{g} / \mathrm{kg}$ [13]. Furthermore, the maximum concentrations of $860 \mu \mathrm{g} / \mathrm{kg}$ and $800 \mu \mathrm{g} / \mathrm{kg}$ were recorded in mussels from Tunisia and France, respectively, while the concentration found in mussels harvested in Spain and Portugal approximated to $5000 \mu \mathrm{g} / \mathrm{kg}$ [58].

Environmental conditions such as temperature, salinity, and food availability differ over the seasons and may influence the physiological status of shellfish, which in turn affects DA depuration kinetics [20]. Blanco et. al. [18] found that the decrease in salinity reduces DA depuration rate in mussels, while changes in water temperature and body weight have no significant effect. Positive correlation between environmental temperature and DA depuration rate was established in P. maximus [38]. In their research of gut passage time of microalgae in mussels and Pacific oysters, Guéguen et al. [48] found no significant effect of algal concentration on passage time in oysters, but did prove the impact of environmental temperature on cell lysis in the digestive tract, presumably linked to the higher activity of the digestive enzymes witnessed at higher temperatures.

This research revealed the maximum DA concentrations in Queen scallops and ascidians to be witnessed in the late autumn. In ascidians, significantly higher DA concentrations were found in December $(p<0.001)$, while in scallops, this was the case in both November and December $(p=0.049)$. In spring and summer, DA concentrations decreased. A significant month-to-month difference in DA concentrations (above LOD) was not seen in oysters $(p=0.868)$ but was evidenced in ascidians and scallops. Figure 2 shows the mean DA concentrations detected monthly in bivalves and ascidians during the one-year study, together with the pertaining standard errors.

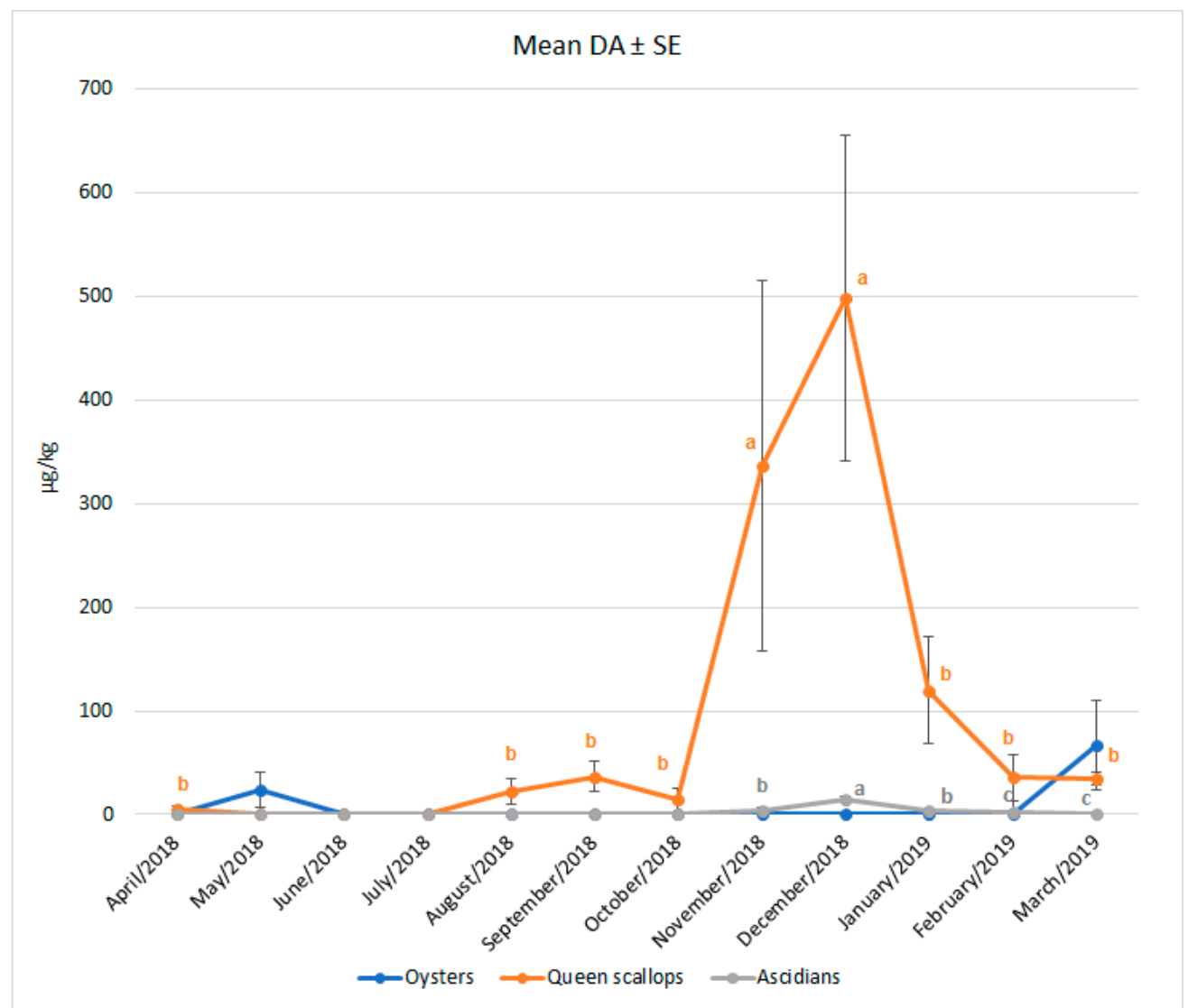

Figure 2. Monthly occurrence of DA in European oysters, Queen scallops and ascidians, detected from April 2018 until March 2019. ${ }^{a, b, c}$ values within the same line (species) tagged with a different superscript differ significantly $(p<0.05)$. Vertical bars denote the standard errors. 
These results conform to those of Stonik and Orlova [59], who reported the presence of DA in Pacific mussels (M. trossulus) from October 2009 to February 2010 in concentrations of up to $100 \mu \mathrm{g} / \mathrm{kg}$. From January to March 2010, DA was found in Mizuhopecten yessoensis scallops collected in the Vostok Bay in the Sea of Japan, with the highest concentration of $90 \mu \mathrm{g} / \mathrm{kg}$ determined in January. Mussel samples collected during the year were DA-free in spring and summer. The findings of this research do not coincide with those of Ljubešić et al. [55] and Ujević et al. [56], who also reported on DA occurrence in the Northern Adriatic Sea. The authors quoted above detected DA in shellfish samples during the warmer part of the year. Ljubešić et al. [55] detected DA in M. galloprovincialis from April until October in concentrations ranging from $97 \mu \mathrm{g} / \mathrm{kg}$ to $872 \mu \mathrm{g} / \mathrm{kg}$, whilst Ujević et al. [56] detected DA from July until November in M. galloprovincialis, F. proteus and P. jacobaeus in the highest concentration of $1657 \mu \mathrm{g} / \mathrm{kg}$, measured in P. jacobaeus in July. Of note, the latter authors reported the maximum DA concentration of $6549 \mu \mathrm{g} / \mathrm{kg}$ in M. galloprovincialis from the Central Adriatic in February 2006, when the lowest sea temperatures in the eight-year period were recorded. One of the possible reasons for differential accumulation of DA in the investigated species could be the discordance in their spawning periods. High energy consumption during the spawning period has a negative impact on the condition index and the tolerance to environmental stress [60-62], especially in broadcast spawners such as scallops $[63,64]$. Since the reproduction pattern is influenced by species characteristics, environmental conditions, and the location [65,66], further research on reproductive cycles of bivalves and ascidians originating from the eastern coast of the Northern Adriatic Sea would be very valuable.

Even though all concentrations measured in this and the aforementioned studies were far below the MPL, it can be assumed that DA may occur in shellfish during any season, even in concentrations above the MPL. This was the case in France, where the maximum DA concentration determined in D. trunculus in spring 1999 equalled to $3200 \mu \mathrm{g} / \mathrm{kg}$, while the next year, during the same period and in the same region, it increased to 53,000 $\mu \mathrm{g} / \mathrm{kg}$ [67].

\section{Conclusions}

Domoic acid was detected in trace levels in three investigated species-European oysters (O.edulis), Queen scallops (A. opercularis), and ascidians of the Microcosmus spp., collected on the eastern coast of the Northern Adriatic Sea throughout the year. Queen scallops accumulated DA more often and in higher concentrations. The highest DA concentrations were found during the colder parts of the year, that is, in ascidians significantly higher in December and in scallops significantly higher in November and December. According to our data, there exists an interspecies variability in DA accumulation, occurrence, and seasonality. The obtained data could be of great value in planning phycotoxin monitoring programmes, in particular at locations at which multiple bivalve species are harvested. This study indicates the need for further research on DA presence in bivalves and other species originating from the eastern coast of the Northern Adriatic Sea that can act as DA vector to humans. Future research should include studies of different abiotic factors that can affect DA accumulation in these species.

\section{Materials and Methods}

\subsection{The Collection of Samples}

Samples were obtained from the same harvesting area in the waters of the northwest coast of the Istrian peninsula, Croatia $\left(\Phi 45^{\circ} 31^{\prime} 30^{\prime \prime} \mathrm{N} \lambda 13^{\circ} 27^{\prime} 18^{\prime \prime} \mathrm{E}\right)$. The Istrian peninsula is situated on the eastern coast of the Northern Adriatic Sea, i.e., in the mostly oligotrophic Adriatic region influenced by the eastern current, oligotrophic karstic rivers, and the northeaster wind-the bora [68]. Samples were collected from April 2018 until March 2019. In total, 46 European oyster, 53 Queen scallop, and 107 ascidian samples were collected during a one-year period. Shellfish were collected from the seabed using dredges; ascidians were also collected using hand tools. Upon collection, samples were immediately 
transported to the laboratory and extracted for subsequent analysis within $24 \mathrm{~h}$ upon arrival. If the analysis was not possible straightaway, the extracts were stored at $-18{ }^{\circ} \mathrm{C}$.

\subsection{Chemicals and Analytical Standard}

The certified CRM-DA-g calibration solution (331.9 $\pm 8.0 \mu \mathrm{mol} / \mathrm{L})$, CRM-FDMT1 (containing $126 \pm 10 \mathrm{mg} / \mathrm{kg}$ of DA $+5^{\prime}$-epi-DA based on the mass of the freeze-dried powder), and toxin-free control mussel tissue matrix CRM (CRM-Zero-Mus) were obtained from the National Research Council Canada's Institute for Marine Bioscience (Halifax, NS, Canada). Chemicals and solvents used were of high and LC-MS purity grade, respectively.

\subsection{Sample Preparation}

Sample extraction and quantification were carried out using dansyl chloride derivatization and LC-MS/MS according to the method described by Beach et al. [69]. As for the ultra-trace analysis, an alternative procedure was used. After DA extraction from bivalve and ascidian soft tissue (100 g) using 50\% aqueous methanol solution, extracts underwent a clean-up on a strong anion-exchange SPE cartridge. The eluate was concentrated using a nitrogen stream and reconstituted in a $50 \%$ aqueous acetonitrile solution. The reconstituted samples were derivatized with DNS-Cl using equal proportions of the reconstituted extract, $150 \mathrm{mM}$ borate buffer aqueous solution, and $5.5 \mathrm{mM}$ DNS-Cl acetonitrile solution. DNS-Cl surplus was removed by liquid-liquid extraction with hexane and analysed using LC-MS/MS. The same procedure was applied to the calibration standards.

\subsection{LC-MS/MS Analyses}

The quantification of DA was performed using a 1290 Infinity UPLC (Agilent Technologies, Singapore) coupled with G6460 Electrospray Ionisation Triple Quad Mass Spectrometer (Agilent Technologies, Waldbronn, Germany). Chromatographic separation was done on a Zorbax SB-C18 RRHT $2.1 \times 50 \mathrm{~mm}, 1.8 \mu \mathrm{m}$ column with SB-C18 $2.1 \times 5 \mathrm{~mm}$, $1.8 \mu \mathrm{m}$ precolumn (Agilent Technologies, Santa Clara, CA, USA), thermostatted at $40{ }^{\circ} \mathrm{C}$. The mobile phase A consisted of $0.2 \%(v / v)$ formic acid in water, while the mobile phase B was composed of $0.2 \%(v / v)$ formic acid in acetonitrile. An isocratic elution with a flow of $0.5 \mathrm{~mL} / \mathrm{min}$ was applied, with the $30.0 \%$-involvement of the organic mobile phase $\mathrm{B}$, and the injection volume of $5 \mu \mathrm{L}$. For the sake of quality control, negative (blank) and positive (spiked) samples were analysed with every sample batch. Quantification was done using an external matrix-matched calibration curve ranging from 1 to $1500 \mu \mathrm{g} / \mathrm{kg}$. The concentrations were corrected using the average recovery values obtained by validation.

\subsection{Validation}

The method was validated in line with the Commission Decision 2002/657/EC [70], applying the InterVAL Plus Software Version 3.4.0.4 (quo data, Gesellschaft für Qualitätsmanagement und Statistik $\mathrm{GmbH}$, Dresden, Germany) for experimental design and calculation of validation parameters. Repeatability and in-house reproducibility were determined by analysing DA in 128 spiked samples consisting of an equal proportion of three bivalve species and ascidians (even though Mediterranean mussels were not under study, they were included in the validation). The limit of detection (LOD) and the limit of quantification (LOQ) were determined in each matrix using the blanks approach, the LOQ thereby being calculated as 3.3 times LOD [29]. To determine the presence of the matrix effect, derivatized standard solutions in water/acetonitrile (1:1) were injected in parallel with derivatized extracts of shellfish and ascidians spiked with the standard DA solution. The value of the calibration curve slope in solvent was compared to the value of slopes of matrix-matched calibration curves. The same comparison was also performed between different matrices. 


\subsection{Statistical Analysis}

Statistical analysis was performed using the SPSS Statistics Software 22.0 (IBM, Armonk, NY, USA). The results were tested for the normality of their distribution using the ShapiroWilks test. In order to determine the statistical significance $(p<0.05)$ of the differences in DA concentrations in different species and sampling months over a one-year period, the non-parametric Kruskal-Wallis test was used.

Author Contributions: Conceptualization, K.K. and J.P.; methodology, K.K. and T.L.; software, T.L.; validation, K.K.; formal analysis, K.K.; investigation, K.K.; resources, K.K. and N.D.; data curation, K.K. and T.L.; writing—original draft preparation, K.K.; writing—review and editing, J.P.; visualization, K.K. and T.L.; supervision, J.P.; funding acquisition, N.D. All authors have read and agreed to the published version of the manuscript.

Funding: This research was funded by the Croatian Veterinary Institute.

Institutional Review Board Statement: Not applicable.

Informed Consent Statement: Not applicable.

Conflicts of Interest: The authors declare no conflict of interest.

\section{References}

1. Dong, F.M. The Nutritional Value of Shellfish in Fisheries, Aquaculture and Seafood. Wash. Sea Grant. Available online: https: / /wsg.washington.edu/wordpress/wpcontent/uploads/publications / Nutritional-Value-of-Shellfish.pdf (accessed on 14 March 2019).

2. Phillips, K.M.; Ruggio, D.M.; Exler, J.; Patterson, K.Y. Sterol composition of shellfish species commonly consumed in the United States. Food Nutr. Res. 2012, 56, 18931. [CrossRef] [PubMed]

3. Rittenschober, D.; Nowak, V.; Charrondiere, R. Review of availability of food composition data for fish and shellfish. Food Chem. 2013, 141, 4303-4310. [CrossRef] [PubMed]

4. Food and Agriculture Organization of the United Nations (FAO). FAO/INFOODS Global Food Composition Database for Fish and Shellfish Version 1.0-uFiSh1.0. Available online: http://www.fao.org/infoods/infoods/tables-and-databases/faoinfoodsdatabases/en/ (accessed on 5 May 2018).

5. Lambert, G.; Karney, R.C.; Rhee, W.Y.; Carman, M.R. Wild and cultured edible tunicates: A review. Manag. Biol. Invasions 2016, 7, 59-66. [CrossRef]

6. O'Mahony, M. EU Regulatory risk management of marine biotoxins in the marine bivalve mollusc food-chain. Toxins 2018, 10, 118. [CrossRef]

7. Nicolas, J.; Hoogenboom, R.L.A.P.; Hendriksen, P.J.M.; Bodero, M.; Bovee, T.F.H.; Rietjens, I.M.C.M.; Gerssen, A. Marine biotoxins and associated outbreaks following seafood consumption: Prevention and surveillance in the 21st century. Glob. Food Secur. 2017, 15, 11-21. [CrossRef]

8. Ciminiello, P.; Fattorusso, E. Bivalve molluscs as vectors of marine biotoxins involved in seafood poisoning. Progr. Mol. Subcell. Biol. 2006, 43, 53-82.

9. Saeed, A.F.; Awan, S.A.; Ling, S.; Wang, R.; Wang, S. Domoic acid: Attributes, exposure risks, innovative detection techniques and therapeutics. Algal Res. 2017, 24, 97-110. [CrossRef]

10. Farabegoli, F.; Blanco, L.; Rodríguez, L.P.; Vieites, J.M.; Cabado, A.G. Phycotoxins in marine shellfish: Origin, occurrence and effects on humans. Mar. Drugs 2018, 16, 188. [CrossRef]

11. Bates, S.S.; Beach, D.G.; Comeau, L.A.; Haigh, N.; Lewis, N.I.; Locke, A.; Martin, J.L.; McCarron, P.; McKenzie, C.H.; Michel, C.; et al. Marine Harmful Algal Blooms and Phycotoxins of Concern to Canada; Fisheries and Oceans Canada: Moncton, NB, Canada, 2020. Available online: https://www.researchgate.net/publication/343365663_Marine_harmful_algal_blooms_and_phycotoxins_of_ concern_to_Canada_Can_Tech_Rep_Fish_Aquat_Sci (accessed on 8 May 2020).

12. Ujević, I.; Roje-Busatto, R.; Ezgeta-Balić, D. Comparison of Amnesic, Paralytic and Lipophilic Toxins profiles in cockle (Acanthocardia tuberculata) and smooth clam (Callista chione) from the central Adriatic Sea (Croatia). Toxicon 2019, 159, 32-37. [CrossRef]

13. Bouchouicha-Smida, D.; Lundholm, N.; Sahraoui, I.; Lambert, C.; Mabrouk, H.H.; Hlaili, A.S. Detection of domoic acid in Mytilus galloprovincialis and Ostrea edulis linked to the presence of Nitzschia bizertensis in Bizerte Lagoon (SW Mediterranean). Estuar. Coast. Shelf Sci. 2015, 165, 270-278. [CrossRef]

14. Takata, Y.; Sato, S.; Viet Ha, D.; Montojo, U.M.; Lirdwitayaprasit, T.; Kamolsiripichaiporn, S.; Kotaki, Y.; Fukuyo, Y.; Kodama, M. Occurrence of domoic acid in tropical bivalves. Fish. Sci. 2009, 75, 473-480. [CrossRef]

15. Picot, C.; Limon, G.; Durand, G.; Wesolek, N.; Parent-Massin, D.; Roudot, A.C. Domoic Acid, Okadaic Acid and Spirolides: Inter-Species Variability in Contamination and Cooking Effects. Food Public Health 2012, 2, 50-57. [CrossRef]

16. Blanco, J.; Mariño, C.; Martín, H.; Álvarez, G.; Rossignoli, A.E. Characterization of the Domoic Acid Uptake Mechanism of the Mussel (Mytilus galloprovincialis) Digestive Gland. Toxins 2021, 13, 458. [CrossRef] 
17. Novaczek, I.; Madhyastka, M.S.; Ablett, R.F.; Donald, A.; Johnson, G.; Nijjar, M.S.; Sims, D.E. Depuration of domoic acid from live blue mussels (Mytilus edulis). Can. J. Fish. Aquat. Sci. 1992, 49, 312-318. [CrossRef]

18. Blanco, J.; Bermúdez de la Puente, M.; Arévalo, F.; Salgado, C.; Moroño, Á. Depuration of mussels (Mytilus galloprovincialis) contaminated with domoic acid. Aquat. Living Resour. 2002, 15, 53-60. [CrossRef]

19. Álvarez, G.; Uribe, E.; Regueiro, J.; Martin, H.; Gajardo, T.; Jara, L.; Blanco, J. Depuration and anatomical distribution of domoic acid in the surf clam Mesodesma donacium. Toxicon 2015, 102, 1-7. [CrossRef] [PubMed]

20. Álvarez, G.; José Rengel, J.; Araya, M.; Álvarez, F.; Pino, R.; Uribe, E.; Díaz, P.A.; Rossignoli, A.E.; López-Rivera, A.; Blanco, J. Rapid Domoic Acid Depuration in the Scallop Argopecten purpuratus and Its Transfer from the Digestive Gland to Other Organs. Toxins 2020, 12, 698. [CrossRef]

21. Trainer, V.L.; Bill, B.D. Characterization of a domoic acid binding site from Pacific razor clam. Aquat. Toxicol. 2004, 69, 125-132. [CrossRef]

22. Blanco, J.; Acosta, C.P.; de la Puente, M.B.; Salgado, C. Depuration and anatomical distribution of the amnesic shellfish poisoning (ASP) toxin domoic acid in the king scallop Pecten maximus. Aquat. Toxicol. 2002, 60, 111-121. [CrossRef]

23. Ventoso, P.; Pazos, A.J.; Pérez-Parallé, M.L.; Blanco, J.; Triviño, J.C.; Sánchez, J.L. RNA-Seq Transcriptome Profiling of the Queen Scallop (Aequipecten opercularis) Digestive Gland after Exposure to Domoic Acid-Producing Pseudo-nitzschia. Toxins 2019, 11, 97. [CrossRef]

24. Dizer, H.; Fischer, B.; Harabawy, A.S.A.; Hennion, M.-C.; Hansen, P.-D. Toxicity of domoic acid in the marine mussel Mytilus edulis. Aquat. Toxicol. 2001, 55, 149-156. [CrossRef]

25. Jones, T.O.; Whyte, J.N.C.; Ginther, N.G.; Townsend, L.D.; Iwama, G.K. Haemocyte Changes In The Pacific Oyster, Crassostrea Gigas, Caused By Exposure To Domoic Acid In The Diatom Pseudonitzschia Pungens F. Multiseries. Toxicon 1995, 33, $347-353$. [CrossRef]

26. Jones, T.O.; Whyte, J.N.C.; Townsend, L.D.; Ginther, N.G.; Iwama, G.K. Effects of domoic acid on haemolymph pH, PCO, and PO, in the Pacific oyster, Crassostrea gigas and the California mussel, Mytilus californianus. Aquat. Toxicol. 1995, 31, 43-55. [CrossRef]

27. Liu, H.; Kelly, M.S.; Campbell, D.A.; Dong, S.L.; Zhua, J.X.; Wang, S.F. Exposure to domoic acid affects larval development of king scallop Pecten maximus (Linnaeus, 1758). Aquat. Toxicol. 2007, 81, 152-158. [CrossRef] [PubMed]

28. Liu, H.; Kelly, M.S.; Campbell, D.A.; Fang, J.; Zhu, J. Accumulation of domoic acid and its effect on juvenile king scallop Pecten maximus (Linnaeus, 1758). Aquaculture 2008, 284, 224-230. [CrossRef]

29. Wenzl, T.; Haedrich, J.; Schaechtele, A.; Robouch, P.; Stroka, J. Guidance Document on the Estimation of LOD and LOQ for Measurements in the Field of Contaminants in Feed and Food. EUR 28099; Publications Office of the European Union: Luxembourg, 2016. [CrossRef]

30. Matuszewski, B.K.; Constanzer, M.L.; Chavez-Eng, C.M. Strategies for the assessment of matrix effect in quantitative bioanalytical methods based on HPLC-MS/MS. Anal. Chem. 2003, 75, 3019-3030. [CrossRef] [PubMed]

31. Zhou, W.; Yang, S.; Wang, P.G. Matrix effects and application of matrix effect factor. Bioanalysis 2017, 9, 1839-1844. [CrossRef]

32. Panuwet, P.; Hunter, R.E., Jr.; D'Souza, P.E.; Chen, X.; Radford, S.A.; Cohen, J.R.; Marder, M.E.; Kartavenka, K.; Bary, R.P.; Boyd, B.D. Biological matrix effects in quantitative tandem mass spectrometry-based analytical methods: Advancing biomonitoring. Crit. Rev. Anal. Chem. 2016, 46, 93-105. [CrossRef]

33. The European Parliament; The Council of the European Union. Regulation (EC) No 853/2004 of the European Parliament and of the Council of 29 April 2004 laying down specific hygiene rules for food of animal origin. Off. J. Eur. Union 2004, 139, 55-205. Available online: http:/ / data.europa.eu/eli/reg/2004/853/oj (accessed on 10 June 2018).

34. Mafra, L.L., Jr.; Bricelj, M.; Ward, J.E. Mechanisms contributing to low domoic acid uptake by oysters feeding on Pseudo-nitzschia cells. II. Selective rejection. Aquat. Biol. 2009, 6, 213-226. [CrossRef]

35. Mafra, L.L., Jr.; Bricelj, M.; Ouellettea, C.; Bates, S.S. Feeding mechanics as the basis for differential uptake of the neurotoxin domoic acid by oysters, Crassostrea virginica, and mussels, Mytilus edulis. Aquat. Toxicol. 2010, 97, 160-171. [CrossRef]

36. Mafra, L.L., Jr.; Bricelj, V.M.; Fennel, K. Domoic acid uptake and elimination kinetics in oysters and mussels in relation to body size and anatomical distribution of toxin. Aquat. Toxicol. 2010, 100, 17-29. [CrossRef] [PubMed]

37. Blanco, J.; Mauríz, A.; Álvarez, G. Distribution of Domoic Acid in the Digestive Gland of the King Scallop Pecten maximus. Toxins 2020, 12, 371. [CrossRef]

38. Blanco, J.; Acosta, C.P.; Mariño, C.; Muñiz, S.; Martín, H.; Moroño, A.; Correa, J.; Arévalo, F.; Salgado, C. Depuration of domoic acid from different body compartments of the king scallop Pecten maximus grown in raft culture and natural bed. Aquat. Living Resour. 2006, 19, 257-265. [CrossRef]

39. Wohlgeschaffen, G.D.; Mann, K.H.; Subba Rao, D.V.; Pocklington, R. Dynamics of the phycotoxin domoic acid: Accumulation and excretion in two commercially important bivalves. J. Appl. Phycol. 1992, 4, 297-310. [CrossRef]

40. Vale, P.; Sampayo, M.A.M. Domoic acid in Portuguese shellfish and fish. Toxicon 2001, 39, 893-904. [CrossRef]

41. Stewart, J.E.; Marks, L.J.; Gilgan, M.W.; Pfeiffer, E.; Zwicker, B.M. Microbial utilization of the neurotoxin domoic acid: Blue mussels (Mytilus edulis) and soft shell clams (Mya arenaria) as sources of the microorganisms. Can. J. Microbiol. 1998, 44, 456-464. [CrossRef]

42. Coma, R.; Ribes, M.; Gili, J.; Hughes, R.N. The ultimate opportunists: Consumers of seston. Mar. Ecol. Prog. Ser. 2001, 219, 305-308. [CrossRef] 
43. MacDonald, B.A.; Bricelj, V.M.; Shumway, S.E. Physiology: Energy Acquisition and Utilisation. In Scallops: Biology, Ecology and Aquaculture, 2nd ed.; Shumway, S., Parsons, G.J., Eds.; Elsevier Science: Amsterdam, The Netherlands, 2006; Volume 40, pp. 417-492.

44. Barillé, L.; Cognie, B. Revival Capacity of Diatoms in Bivalve Pseudofaeces and Faeces. Diatom Res. 2000, 15, 11-17. [CrossRef]

45. Armsworthy, S.L.; MacDonald, B.A.; Ward, E. Feeding activity, absorption efficiency and suspension feeding processes in the ascidian, Halocynthia pyriformis (Stolidobranchia: Ascidiacea): Responses to variations in diet quantity and quality. J. Exp. Mar. Biol. Ecol. 2001, 260, 41-69. [CrossRef]

46. Robbins, I.J. Food Passage and Defaecation an Ciona intestinalis (L.); The Effects of Suspension Quantity and Quality. J. Exp. Mar. Biol. Ecol. 1985, 89, 241-254. [CrossRef]

47. Jacobi, Y.; Shenkar, N.; Ward, J.E.; Rosa, M.; Ramon, G.Z.; Shavit, U.; Yahel, G. Evasive plankton: Size-independent particle capture by ascidians. Limnol. Oceanogr. 2021, 66, 1009-1020. [CrossRef]

48. Guéguen, M.; Lassus, P.; Laabir, M.; Bardouil, M.; Baron, R.; Séchet, V.; Truquet, P.; Amzil, Z.; Barillé, L. Gut passage times in two bivalve molluscs fed toxic microalgae: Alexandrium minutum, A. catenella and Pseudo-nitzschia calliantha. Aquat. Living Resour. 2008, 21, 21-29. [CrossRef]

49. Mauriz, A.; Blanco, J. Distribution and linkage of domoic acid (amnesic shellfish poisoning toxins) in subcellular fractions of the digestive gland of the scallop Pecten maximus. Toxicon 2010, 55, 606-611. [CrossRef] [PubMed]

50. Freitas, J.C.; Ogata, T.; Veit, C.H.; Kodama, M. Occurrence of Tetrodotoxin and Paralytic Shellfish Toxins in Phallusia nigra (Tunicata, Ascidiacea) From the Brazilian Coast. J. Venom. Anim. Toxins 1996, 2, 28-38. [CrossRef]

51. López-Rivera, A.; Pinto, M.; Insinilla, A.; Suárez Isla, B.; Uribe, E.; Alvarez, G.; Lehane, M.; Furey, A.; James, K.J. The occurrence of domoic acid linked to a toxic diatom bloom in a new potential vector: The tunicate Pyura chilensis (piure). Toxicon 2009, 54, 754-762. [CrossRef] [PubMed]

52. Roje-Busatto, R.; Ujević, I. PSP toxins profile in ascidian Microcosmus vulgaris (Heller, 1877) after human poisoning in Croatia (Adriatic Sea). Toxicon 2014, 79, 28-36. [CrossRef]

53. Ciminiello, P.; Dell'Aversano, C.; Fattorusso, E.; Forino, M.; Magno, G.S.; Tartaglione, L.; Quilliam, M.A.; Tubaro, A.; Poletti, R Hydrophilic interaction liquid chromatography/mass spectrometry for determination of domoic acid in Adriatic shellfish. Rapid Commun. Mass Spectrom. 2005, 19, 2030-2038. [CrossRef]

54. Arapov, J. A Review of shellfish phycotoxin profile and toxic phytoplankton species along Croatian coast of the Adriatic Sea. Acta Adriat. 2013, 54, 283-298.

55. Ljubešić, Z.; Bosak, S.; Viličić, D.; Kralj Borojević, K.; Marić, D.; Godrijan, J.; Ujević, I.; Peharec, P.; Đakovac, T. Ecology and taxonomy of potentially toxic Pseudo-nitzschia species in Lim Bay (north-eastern Adriatic Sea). Harmful Algae 2011, 10, 713-722. [CrossRef]

56. Ujević, I.; Ninčević-Gladan, Ž.; Roje, R.; Skejić, S.; Arapov, J.; Marasović, I. Domoic Acid-A New Toxin in the Croatian Adriatic Shellfish Toxin Profile. Molecules 2010, 15, 6835-6849. [CrossRef]

57. Rijal Leblad, B.; Lundholm, N.; Goux, D.; Veron, B.; Sagou, R.; Taleb, A.; Nhhala, H.; Er-Raioui, H. Pseudo-nitzschia Peragallo (Bacillariophyceae) diversity and domoic acid accumulation in tuberculate cockles and sweet clams in M'diq Bay, Morocco. Acta Bot. Croat. 2013, 72, 35-47. [CrossRef]

58. Hassoun, A.E.R.; Ujević, I.; Mahfouz, C.; Fakhri, M.; Roje-Busatto, R.; Jemaa, S.; Nazlić, N. Occurrence of domoic acid and cyclic imines in marine biota from Lebanon-Eastern Mediterranean Sea. Sci. Total Environ. 2020, 755, 142542. [CrossRef] [PubMed]

59. Stonik, I.V.; Orlova, T.Y. The Seasonal Accumulation of Amnesic Toxin (Domoic Acid) in Commercial Bivalves Mytilus trossulus Gould, 1850 and Mizuhopecten yessoensis Jay, 1850 in Vostok Bay, Sea of Japan. Russ. J. Mar. Biol. 2020, 46, 56-58. [CrossRef]

60. Li, Y.; Qin, J.G.; Abbott, C.A.; Li, X.; Benkendorff, K. Synergistic impacts of heat shock and spawning on the physiology and immune health of Crassostrea gigas: An explanation for summer mortality in Pacific oysters. Am. J. Physiol. Regul. Integr. Comp. Physiol. 2007, 293, 2353-2362. [CrossRef]

61. Li, Y.; Qin, J.G.; Abbott, C.A.; Li, X.; Benkendorff, K. Monthly variation of condition index, energy reserves and antibacterial activity in Pacific oysters, Crassostrea gigas, in Stansbury (South Australia). Aquaculture 2009, 286, 64-71. [CrossRef]

62. Li, Y.; Qin, J.G.; Abbott, C.A.; Li, X.; Benkendorff, K. Spawning-dependent stress response to food deprivation in Pacific oyster Crassostrea gigas. Aquaculture 2009, 286, 309-317. [CrossRef]

63. Brokordt, K.; Pérez, H.; Herrera, C.; Gallardo, A. Reproduction reduces HSP70 expression capacity in Argopecten purpuratus scallops subject to hypoxia and heat stress. Aquat. Biol. 2015, 23, 265-274. [CrossRef]

64. Brokordt, K.; Defranchi, Y.; Espósito, I.; Cárcamo, C.; Schmitt, P.; Mercado, L.; de la Fuente-Ortega, E.; Rivera-Ingraham, G.A. Reproduction Immunity Trade-Off in a Mollusk: Hemocyte Energy Metabolism Underlies Cellular and Molecular Immune Responses. Front. Physiol. 2019, 10, 77. [CrossRef]

65. Turon, X. The ascidians of Tossa de Mar (Girona, NE of Spain). II.-Biological cycles of the colonial species. Cah. Biol. Mar. 1988, 29, 407-418.

66. Raijman Nagar, L.; Shenkar, N. From Tropical to Sub-Tropical: Prolonged Reproductive Activity of the Invasive Ascidian Microcosmus exasperatus in the Eastern Mediterranean. Front. Ecol. Evol. 2016, 4, 102. [CrossRef]

67. Amzil, Z.; Fresnel, J.; Dominique Le Gal, D.; Billard, C. Domoic acid accumulation in French shellfish in relation to toxic species of Pseudo-nitzschia multiseries and P. pseudodelicatissima. Toxicon 2001, 39, 1245-1251. [CrossRef] 
68. Viličić, D.; Đakovac, T.; Zrinka, B.; Bosak, S. Composition and annual cycle of phytoplankton assemblages in the northeastern Adriatic Sea. Bot. Mar. 2009, 52, 291-305. [CrossRef]

69. Beach, D.G.; Liu, H.; Quilliam, M.A. Sensitive determination of domoic acid in mussel tissue using dansyl chloride derivatization and liquid chromatography-mass spectrometry. Anal. Methods 2014, 7, 1000-1007. [CrossRef]

70. EC-European Commission. Commission Decision 2002/657/EC of 12th August 2002 implementing Council Directive 96/23/EC concerning the performance of analytical methods and the interpretation of results. Off. J. Eur. Communities 2002, 50, 8-36. 